\title{
Effect of temperature on rheological characteristics of ginger paste
}

\author{
J. Ahmed \\ Department of Food Sciences, College of Food Systems, United Arab Emirates University, \\ Al Ain, P.O. Box 17555, United Arab Emirates, E-mail: jahmed@uaeu.ac.ae

\begin{abstract}
The influences of temperature $\left(25-65^{\circ} \mathrm{C}\right)$ on the rheological characteristics of ginger paste were studied using a rheometer. Shear stress, shear rate and apparent viscosity of paste were measured between 50 and $150 \mathrm{~s}-1$. Ginger paste showed pseudoplasticity with yield stress. Shear stress-shear rate data was well described by the Herschel-Bulkley model. The yield stress decreased exponentially with process temperature and ranged between 63.3 and $159.2 \mathrm{~Pa}$. The flow behavior index (n) varied between 0.52 and 0.66 through the entire temperature range. Both consistency index $(\mathrm{K})$ and apparent viscosity $(\eta)$ decreased with the increase in temperature and the process activation energies of flow were found to be in the range of 34.4 and $46.2 \mathrm{~kJ} / \mathrm{mol}$.
\end{abstract}

Key Words: ginger, yield stress, consistency coefficient, flow behavior index, activation energy.

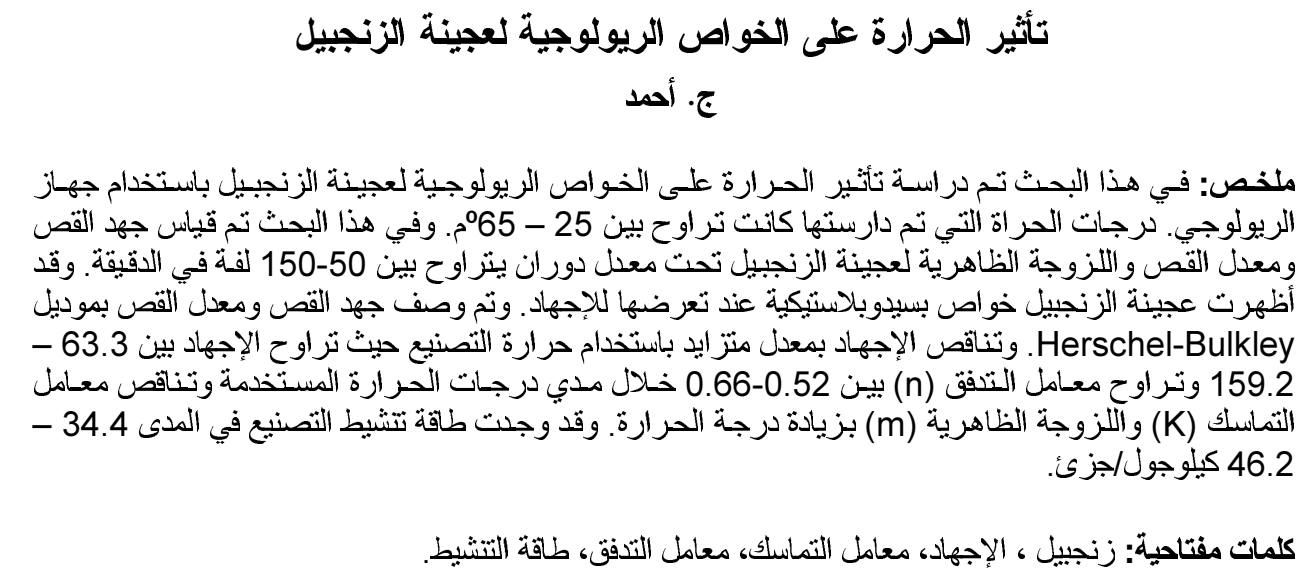

\section{Introduction}

Spices, the aromatic vegetable materials, are used to flavor and season foods. These are valued not only as piquant flavoring agents but also as appetite stimulants. Some spices possess antioxidant properties, while others are used as natural food preservatives. Many of these spices possess medicinal properties and have profound effects on human health. Recent health, nutritional and ecological considerations have resulted in an increasing awareness for 'natural' foods. Spices, being materials of plant origin, are more appealing to the consumer than synthetic food additives. Ginger (Zingiber officinale) is one of the important spices. The rhizome of ginger in its fresh as well as dried form has been used both in medicine and as a spice for several centuries. The spice is extensively grown in the tropics, and the main exporting countries are India, Nigeria, Australia, China and Jamaica. Fresh spices are perishable in nature and the causes of spoilage are improper handling, growth of spoilage microorganisms, reaction of naturally occurring enzymes and chemicals, and structural changes during storage. The post-harvest losses of these spices are high but could be considerably reduced if processed immediately after the harvest. Drying is one of the oldest and most widely practiced methods of preservation. However the scope of drying is limited because the volatile oils and chemical compounds responsible for 
pungent flavors, especially gingerols and pigments are highly heat sensitive (Baranowski, 1985; Pezzutti and Crapiste, 1997). Loss of volatile oils from dehydrated ginger can be substantial and it has been reported that ground ginger can lose up to $50 \%$ of its volatile oils during storage depending upon packaging material used (Richardson, 1967; Govindarajan, 1982). Therefore, there is an urgent need to explore alternate processes for preservation of ginger and to develop products based on these. Ginger paste is one such alternate product, which can be stored for longer periods without much alteration from the fresh material and can be considered as minimally processed food (Baranowski, 1985; Ahmed and Shivhare, 2001a, b; Ahmed et al. 2002a, 2002b). Recently the market of spice paste has increased manifold with the success of fast food industries.

Knowledge of rheological properties is important to food scientists for various reasons. Rheology provides guidelines in defining a set of parameters, which can be used to correlate with quality attributes of food products (Toledo, 1997). Information about the rheological characteristics of food products is used by food engineers to design processing parameters and flow characteristics of the fluid foods. Rheological characteristics of paste depend on various factors like temperature, composition, total soluble solids, and particle size, and may also depend on the rate of shear or shear stress, the duration of shear as well as previous shear history. Correct flow characterization of ginger paste could help processors to develop new products and formulations.

Studies on rheology of ginger paste are limited (Baranowski 1985; Ahmed 2003). Therefore, the present study was undertaken to investigate the effect of temperature on rheological characteristics of ginger paste.

\section{Materials and Methods}

Preparation of puree

Mature ginger rhizomes were procured locally and stored at $25 \pm 1{ }^{\circ} \mathrm{C}$ until processing. The storage period was only one week. Ginger rhizomes were peeled, cut and processed into puree using a laboratory size grinder. The puree was passed through a 1-mm sieve to obtain a uniform consistency.

Preparation of paste

Paste was characterized as the product obtained after adding common salt and organic acid to puree. The paste was prepared by adding common salt of $7 \%$ $(\mathrm{w} / \mathrm{w})$ to ginger puree to increase its total soluble solids (TSS). The fresh ginger puree had a $\mathrm{pH}$ of 6.43 and was adjusted to approximately 4.0 by adding $30 \%$ citric acid solution (w/v). It is established that an acidified food $(\mathrm{pH}$ 4.6) requires only pasteurization (Garcia et al., 1999) and could retain fresh spice odor (Baranowski, 1985). The paste was therefore, thermally processed at $80^{\circ} \mathrm{C}$ for $15 \mathrm{~min}$ and packaged immediately in glass containers.

Rheological measurement

Rheological characteristics (shear stress, shear rate, and apparent viscosity) of ginger paste were measured directly with a Brookfield RVDV-III rheometer (Brookfield Eng. Lab. Inc., Stoughton, MA, USA) in the temperature range of 25 to $65^{\circ} \mathrm{C}$. A sample volume of approximately $10 \mathrm{~mL}$ was placed in the sample compartment. The SCR-21/13R spindle was selected for the measurement. Shear stress, shear rate and apparent viscosity of paste were recorded between 50 and $150 \mathrm{~s}^{-1}$. Thermostatic water bath (TC 500) provided with the instrument was used to regulate the sample temperature. 
Emir. J. Agric. Sci. 2004. 16 (1) : 43 - 49

http://www.cfs.uaeu.ac.ae/research/ejas.html

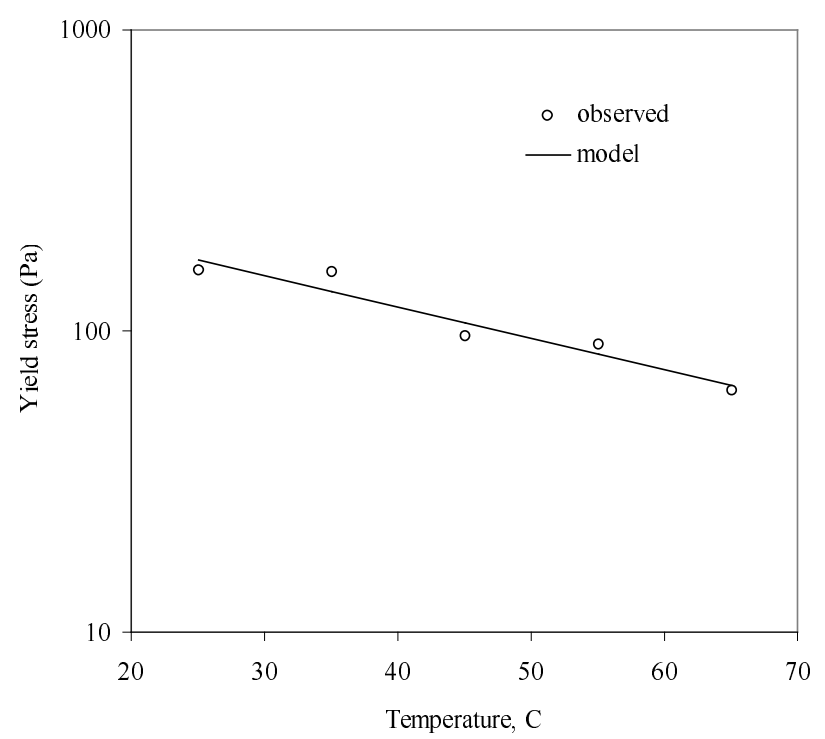

Figure 1.Variation of yield stress with temperature of ginger paste

Flow models used

Various rheological models (Newtonian, Power Law, Casson and Herschel-Bulkley) have been tested to fit the experimental shear stress-shear rate data. The Herschel-Bulkley model has generally been used to predict the flow characteristics of non-Newtonian foods involving shear stress and shear rate. The model is very convenient as Newtonian, power law, or Bingham plastic behavior may be considered as special cases (Steffe 1992). The model is represented as:

$\tau-\tau_{0}=\mathrm{K}(\gamma)^{n}$

The yield stress has been calculated by Casson model and the yield depends on the data range used in the analysis (Steffe 1992). Casson model is expressed as:

$\tau^{0.5}=\mathrm{K}_{0}+\mathrm{K}(\gamma)^{0.5}$

The temperature dependence of apparent viscosity $(\eta)$ at constant shear rate and consistency coefficient (K) can be described by the Arrhenius model:

$\eta=A_{\eta} \exp \left(E_{\eta} / R_{a}\right)$

$\mathrm{K}=\mathrm{A}_{\mathrm{K}} \exp \left(\mathrm{E}_{\mathrm{K}} / \mathrm{RT}_{\mathrm{a}}\right)$
Each experiment was replicated twice and the average values were taken for data analysis.

Physico-chemical properties

Total soluble solids ( ${ }^{\circ}$ Brix) and $\mathrm{pH}$ were determined using a refractrometer (Atago, Japan) and a pH-meter with glass electrode (Systronics, India) at $20^{\circ} \mathrm{C}$, respectively.

\section{Statistical analysis}

Statistical analysis was carried out using as per method described by Gacula and Singh (1994). Trends were considered significant while means of compared sets differed at $\mathrm{P}<0.05$.

\section{Results and Discussion}

Rheological behavior of ginger paste

The yield stress was calculated from the intercept of Casson model $\left(\tau_{0}=\mathrm{K}_{0}{ }^{2}\right)$ by linear regression of the square roots of shear rate and shear stress $\left(\mathrm{R}^{2}>0.92\right)$. The yield stress values varied between 63.3 and 159.2 $\mathrm{Pa}$ for the temperature range of 25 to $65^{\circ} \mathrm{C}$ Figure 1. The yield values decreased with process temperature. An attempt was made to model yield stress with temperature and 
Table 1. Fitting of various models at $35^{\circ} \mathrm{C}$

\begin{tabular}{lcc}
\hline \multicolumn{1}{c}{ Model } & $\begin{array}{c}\text { Coefficient of } \\
\text { determination (R2) }\end{array}$ & $\begin{array}{c}\text { Standard } \\
\text { error }\end{array}$ \\
\hline Newtonian & 0.865 & 10.23 \\
Power law & 0.937 & 0.032 \\
Casson & 0.922 & 0.261 \\
Herschel-Bulkley & 0.960 & 0.045 \\
\hline
\end{tabular}

Table 2. Herchel-Bulkley model coefficients for ginger paste

\begin{tabular}{ccccc}
\hline $\begin{array}{c}\text { Temperature } \\
\left({ }^{\mathbf{0}} \mathbf{C}\right)\end{array}$ & $\begin{array}{c}\text { Consistency } \\
\text { coefficient } \\
\left(\mathbf{P a . s}^{\mathbf{n}}\right)\end{array}$ & $\begin{array}{c}\text { Flow behaviour } \\
\text { index } \\
\text { (Dimensionless) }\end{array}$ & $\mathbf{R}^{\mathbf{2}}$ & $\begin{array}{c}\text { Standard } \\
\text { error }\end{array}$ \\
\hline 25 & 269.88 & 0.553 & 0.965 & 0.078 \\
35 & 120.93 & 0.566 & 0.960 & 0.095 \\
45 & 115.51 & 0.515 & 0.955 & 0.088 \\
55 & 41.13 & 0.663 & 0.960 & 0.162 \\
65 & 29.30 & 0.575 & 0.988 & 0.092 \\
\hline
\end{tabular}

it was found that exponential model (Eq. 5) fitted well $\left(\mathrm{R}^{2}>0.93\right.$ and standard error $<$ $0.12)$ compared to linear one $\left(\mathrm{R}^{2}>0.91\right.$ and standard error $<14.60$ ).

$$
\tau_{\mathrm{o}}=\mathrm{k}_{1} \exp \left(\mathrm{k}_{2} \mathrm{~T}\right)
$$

The coefficients of the Equation (5) were 5.75 and -0.024 respectively. Figure 1 presents the exponential behavior of yield stress with process temperature.

Among various models, the best fit was selected on the basis of the coefficient of determination $\left(\mathrm{R}^{2}\right)$ and standard error. The magnitudes of $\mathrm{R}^{2}$ and standard errors of various models at $35^{\circ} \mathrm{C}$ are shown in Table 1. Yield values of selected temperature were incorporated in the shear stress value and the shear stress-shear rate data the Herschel Bulkley model (Equation 1) adequately for the entire temperature range. The regression coefficients of the Herschel-Bulkley model are reported in Table 2. In all cases, $\mathrm{R}^{2}$ was greater than 0.96 and standard error was less than 0.16. Typical flow curve for ginger paste is shown in Figure 2. The flow behavior index, $n$, of paste ranged between 0.51 and
0.66 and behaved as a pseudoplastic fluid. There was no trend found for flow behavior index of ginger paste. Similar observations for various puree/paste were reported by various researchers (Harper and El Sahrigi, 1965; Saravacos, 1970; Duran and Costell, 1982; Ibarz et al., 1995; Ahmed et al., 1999).

Effect of temperature on consistency index and apparent viscosity

Apparent viscosity $(\eta)$ and consistency coefficient (K) decreased significantly $(\mathrm{P}<0.05)$ with increase in temperature of paste. It is seen that for ginger paste $\mathrm{K}$ decreased from a value of 269.9 to 29.3 Pa.s ${ }^{n}$ while the corresponding values of $\eta$ ranged between 791.2 and 145.8 Pa.s. The Arrhenius model (Equations 3 and 4) described well the dependence of apparent viscosity at a shear rate of $0.37 \mathrm{~s}^{-1}$ and the consistency index of the Herschel-Bulkley model on temperature (Figure 3). 
Emir. J. Agric. Sci. 2004. 16 (1) : 43 - 49

http://www.cfs.uaeu.ac.ae/research/ejas.html

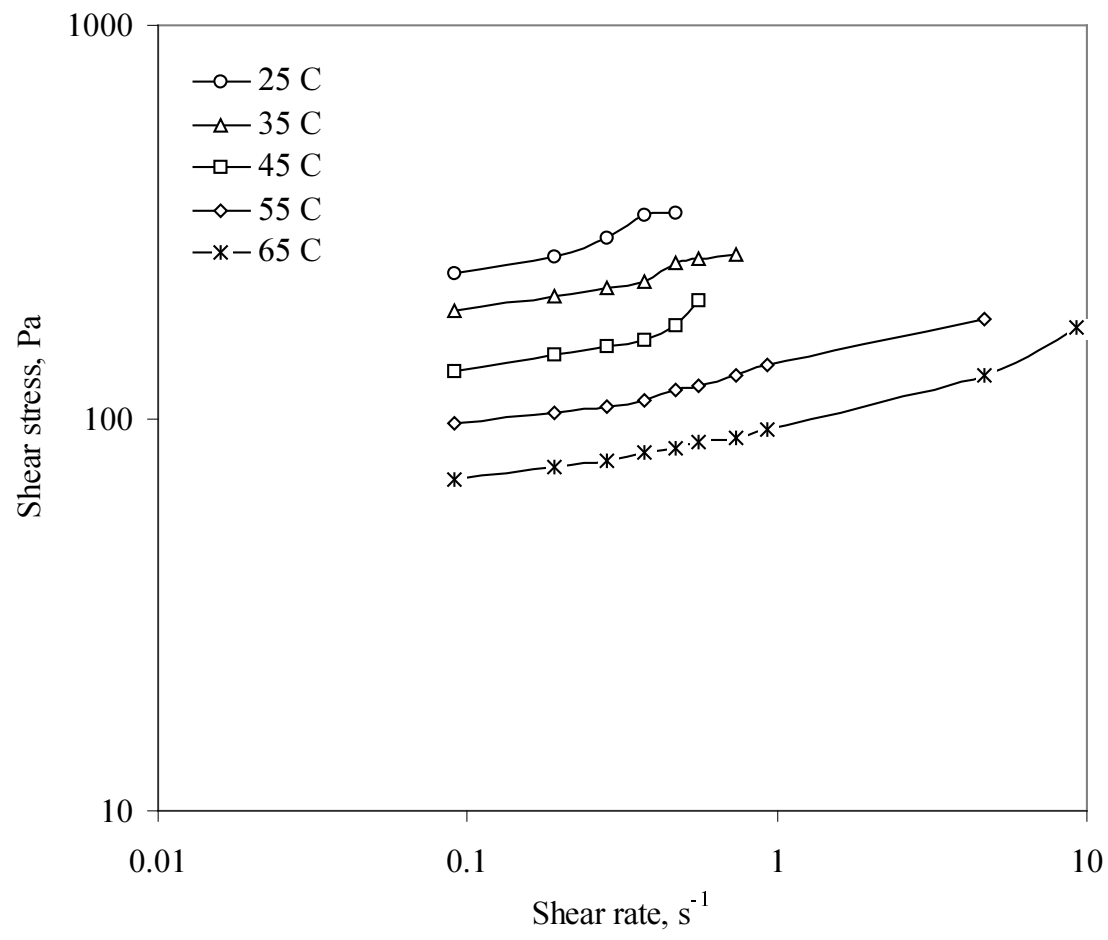

Figure 2.Reheogram of ginger paste at selected temperature

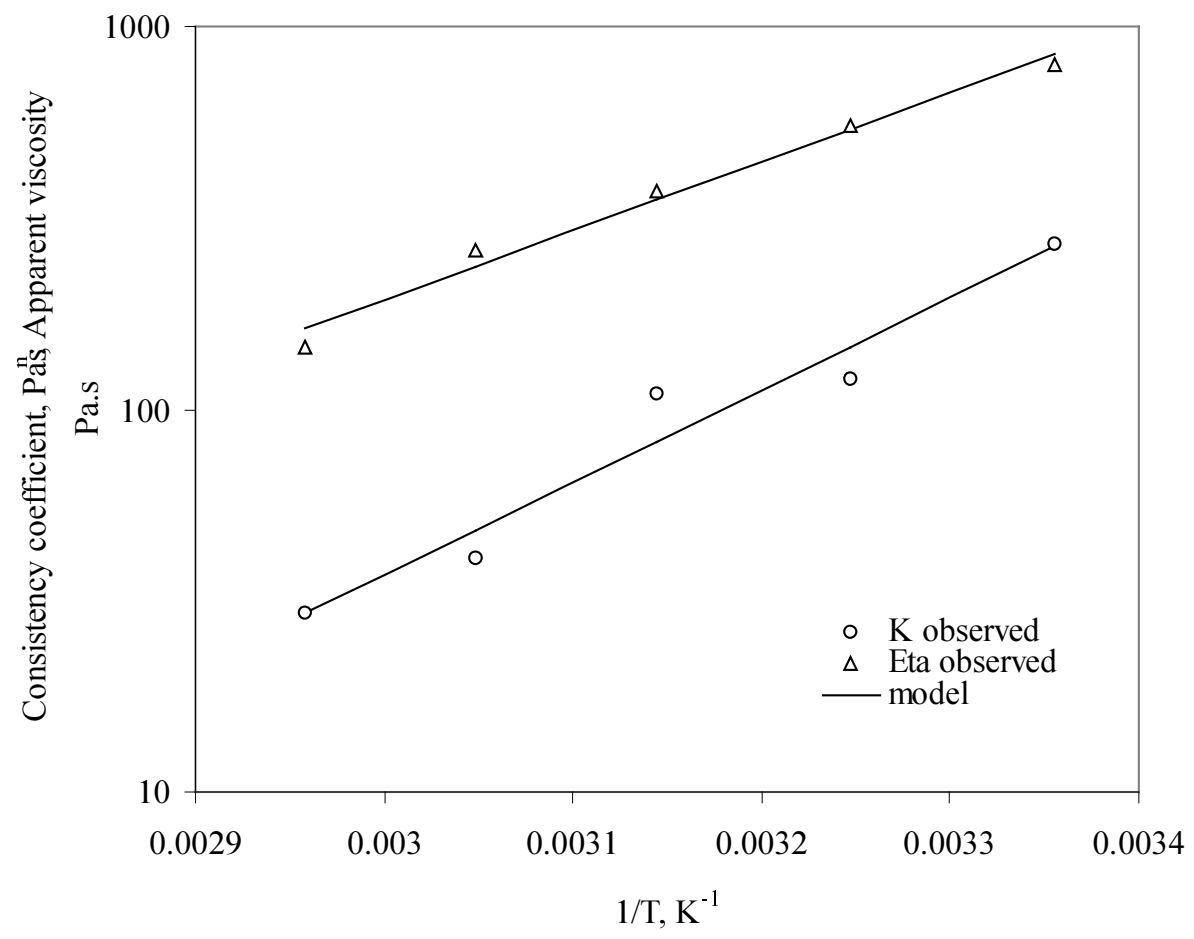

Figure 3. Temperature dependence of consistency coefficient and apparent viscosity of ginger paste 
The coefficients of Equation (3) and (4) were computed using the least square technique $\left(\mathrm{R}^{2}>0.95\right)$. The computed values of $A_{\eta}$ and $E_{\eta}$ were $7.8 \times 10^{-4}$ Pa.s and 34.4 $\mathrm{kJ} / \mathrm{mol}$, respectively, while $A_{k}$ and $E_{k}$ were $2.2 \times 10^{-6}$ and $46.2 \mathrm{~kJ} / \mathrm{mol}$, respectively. The activation energy values are consistent with earlier reports in the literature for pureed foods (Vitali and Rao 1982; Manohar et al., 1991). The substantial variation in the magnitude of $\mathrm{K}$ and $\eta$ between 25 and $65^{\circ} \mathrm{C}$ were useful in characterizing the flow behavior due to temperature and must be an important consideration in the design of handling systems.

\section{Conclusion}

Fresh ginger was converted to paste with the addition of common salt and citric acid and thermally processed at $80^{\circ} \mathrm{C}$ for 15 min. The paste exhibited pseudoplasticity with yield stress and the rheological behaviour was adequately described by the Herschel-Bulkley model. The yield stress decreased exponentially with process temperature. The flow activation energies of the paste ranged between 34.4 and 46.2 $\mathrm{kJ} / \mathrm{mol}$.

\section{References}

Ahmed, J. 2003. Rheological behaviour and color changes of ginger paste during storage. Intl. J. Food Sci \& Technol. In Press.

Ahmed, J., H. Gangopadhaya and U. S. Shivhare. 1999. Effect of temperature on rheological charactersitics of green chilli puree. J. Food Sci. Technol. 36: 352-354.

Ahmed, J. and U. S. Shivhare. 2001a. Thermal kinetics of color change, rheology and storage characteristics of garlic puree/paste. J. Food Sci. 66: 754-757.

Ahmed, J. and U. S. Shivhare. 2001b. Thermal kinetics of color degradation and storage Characteristics of onion paste. Lebensm-Wisst u-Technol. 33: 380-383.

Ahmed, J., U. S. Shivhare and S. Debnath. 2002a. Color degradation and rheology of green chilli puree during thermal processing. Inter. J. Food Sci.Technol. 37: 57-64.

Ahmed, J., U. S. Shivhare and H. S. Ramaswamy. 2002b. A Fraction Conversion Kinetic Model for Thermal Degradation of Color in Red Chilli Puree and Paste. Lebensm-Wiss-uTechnol. 35:497-503.

Baranowski, J. D. 1985. Storage stability of a processed ginger paste. J. Food Sci. 50:932-933.

Duran, L. and E. Costell. 1982. Rheology of apricot puree: characterization of flow. J. Tex. Studies. 13: 43-58.

Gacula, M. C. and J. Singh. 1994. Statistical Methods in Food and Consumer Research. Academic Press, London.

Garcia, P., M. Brenes, C. Romero and A. Garrido. 1999. Color and texture of acidified ripe olives in pouches. J. Food Sci. 64: 218-251.

Govindarajan, V. S. 1982. Gingerchemistry, technology and quality evaluation: Part 2, CRC Crit. Review in Food Sci. \& Nutr. 17:189-258.

Harper, J. C. and A. F. El-Sahrigi. 1965. Viscometric behaviour of tomato 
Emir. J. Agric. Sci. 2004. 16 (1) : 43 - 49

http://www.cfs.uaeu.ac.ae/research/ejas.html

concentrates. Food Technol. 30: 470476.

Ibarz, A., J. Giner, J. Pagan, V. Gimeno and S. Garza. 1995. Rheological behaviour of kiwi fruit juice concentrates. J. Tex. Studies. 26: 137-145.

Manohar, B., P. Ramakrishna and K. Udayasankar. 1991. Some physical properties of tamarind (Tamarindus indica L.) juice concentrates. J. Food Eng. 13: 241-258.

Pezzutti, A. and G. H. Crapiste. 1997. Sorptional equilibrium and drying characteristics of garlic. J. Food Eng. 31: 113-123.
Richardson, K. C. 1967. The packaging and storage of dried ginger. Food Technol. Australia. 19: 165-167.

Saravacos, G. D. 1970. Effect of temperature on viscosity of fruit juices and purees. J. Food Sci. 35: 122-125.

Steffe, J. F. 1992. Rheological Methods in Food Process Engineering, Freeman Press, Michigan, USA.

Toledo, R. T. 1997. Fundamentals of Food Process Engineering. CBS Publication, New Delhi.

Vitali, A. A. and M. A. Rao. 1982. Flow behavior of guava puree as a function of temperature and concentration. J. Tex. Studies. 13: 275-289. 